\title{
10 Governance of water based on responsible use - an elegant solution?
}

\author{
Linda Te Aho
}

\section{Introduction}

The Earth is the elemental womb to which we must all return. For the future, despite the depletion and abuse of natural resources, we must find hope in the wisdom of the past. ${ }^{1}$

The inspiration for this chapter is a proposal said to represent "a paradigm shift" for the governance of freshwater, articulated by Sir Edward Taihakurei Durie in $2014 .{ }^{2}$ Arising out of challenges to a government plan to sell its shares in powergenerating companies, ${ }^{3}$ the Durie proposal has at its heart a possibility for reconciling Māori rights and interests and wider general interests in freshwater. It is based on the assumption that Māori and the general public have a legitimate interest in the natural water regimes of the country. However, the source of the interest is not the same. The Māori interest is proprietary and is sourced in their status as the indigenous first peoples of the land who were guaranteed continuation of their tino rangatiratanga in respect of their lands and waters in Te Tiriti o Waitangi. ${ }^{4}$ The public interest is sourced in the British laws that superimposed Māori laws through processes of colonisation. The heart of the Durie proposal is that those utilising water for commercial purposes should be charged and that an independent commission would be responsible for overseeing charging and revenue collection and disbursement. A proportion of the funds would be allocated to Māori authorities in recognition of the Māori interest. Whether in public or Māori hands, the funds should be applied to the maintenance or improvement of the natural water bodies of the area or the assurance of water supplies to all homes. In short, the proposal focuses upon responsibility.

The philosophy of responsibility refers to the respectful relationship human beings can have with their social and natural environment. In New Zealand, it is said, worldviews upon which the philosophy is based "find their expression in the culture, knowledge and lifeways of the Māori who see themselves as part of a familial web in which humans are junior siblings to other species, beings and forms of life." Proponents of responsibility emphasise "responsiveness", an ability to respond to challenges and changes in the environment. ${ }^{6}$ This chapter traces some of the history of Māori responsiveness to the historical and continued 


\section{Linda Te Aho}

dispossession and destruction of their lands and waters. These violations are closely tied to global environmental challenges such as climate change, water scarcity and food security. ${ }^{7}$ The framework of Māori responses to these challenges appears to have been one of rights. However, it is a theme of this chapter that a key driver in the assertion of Māori rights has been the desire to fulfil stated responsibilities to the natural world and to future generations.

This has led to a "curious situation"8 in which there is a growing trend towards collaboration between the govemment and Māori in managing natural resources and a greater respect for ecosystems. At the same time, New Zealand faces a freshwater crisis aided and abetted by the government's reluctance to recognise Māori proprietary rights in water.

The wisdom behind the Durie proposal is that it promotes a change in jurisprudence away from focusing upon rights-based mechanisms and language of ownership, towards restoration and collaborative governance based on shared responsibility - a seemingly elegant solution.

This chapter draws upon domestic case studies to illustrate the strong similarities between indigenous laws and values and the principles of responsibility. It provides insights into how such "wisdom of the past" might be applied in contemporary contexts and help to shape the future of how well we live on this planet. It also contains a cautionary note about settling into a culture of compromise.

\section{A changing legal landscape}

New Zealand is a water-rich nation, and despite its reputation for being "clean and

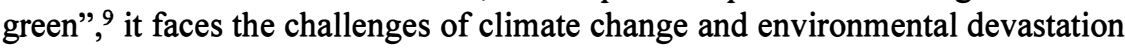
as a result of the over-exploitation of ecosystems. New Zealand is very slowly coming to grips with "the impacts of raised water temperatures and wildly swinging weather extremes from drought to flood." ${ }^{10}$ Climate change expert, Dr Adrian Macey, ${ }^{11}$ has warned of the risks of New Zealand continuing to deforest and farm in ways that have led to erosion and to contaminants such as E. coli, nitrogen and phosphorus leaching into freshwater streams and rivers - many of which are no longer drinkable or swimmable, or even wadeable. ${ }^{12} \mathrm{And}$, there is still no solution on the horizon for dealing with the unfair distribution and allocation of water. ${ }^{13}$

We have arrived at this point as a result of adhering to principles of British common law that reflect a Western worldview in relation to the environment, and in particular the anthropocentric notion that ${ }^{14}$

Wonders are many on earth, and the greatest of these is man ... He is master of ageless Earth, to his own will bending ... He is lord of all things living; birds of the air, beasts of the field, all creatures of sea and land.

In this tradition, at common law there has never been ownership in naturally flowing water. Rights to water resources were derived from land ownership. For the purpose of determining the extent of such rights, and providing regulation for public interests such as for navigation and consents for the use of natural 
resources such as minerals, rivers were separated into beds, banks, and waters, and into tidal and non-tidal, navigable and non-navigable parts, and lakes were separated in similar ways. The common law presumed that owners and occupiers of adjacent land had rights to take and use water on or under that land subject to certain restrictions. They were also entitled to riparian rights to the beds and banks of rivers and lakes. ${ }^{15}$

Such precepts were foreign to Māori, who had their own conceptions of waterways and their own laws regulating use and control. From the 1840s, when these British laws were superimposed in New Zealand, water law and policy focused on allocating and protecting individual rights to water resources in response to the needs of colonial settlers. ${ }^{16}$ Rivers and streams could be declared public drains. ${ }^{17}$ Wetlands were drained for agricultural production. ${ }^{18}$ Conservation did not become a priority in water management in New Zealand until 1967 when the Water and Soil Conservation Act (WSCA) was enacted.

The WSCA represented a profound change to the law in terms of incorporating conservation values into legislation. However, the Waitangi Tribunal highlighted the absence of Māori cultural values as a flaw and recommended that the legislation be amended..$^{19} \mathrm{~A}$ further shift occurred in 1987 as a result of a landmark High Court decision, the Huakina case, ${ }^{20}$ which imported Māori spiritual and cultural values as criteria governing the Planning Tribunal's functions under the WSCA. The case was led by Nganeko Minhinnick (who later became Dame Nganeko) and the Huakina Development Trust, who opposed an application for consent to discharge treated dairy shed waste into a stream, relying upon the Treaty of Waitangi and the spiritual values and relationship of Māori to the waters of the region. Since the WSCA was silent as to the criteria governing applications, the court ruled that Waitangi Tribunal interpretations of the Treaty could assist to ascertain Māori spiritual values. The Huakina litigation was part of a comprehensive and deliberate strategy by Māori in the Waikato region of raising concerns about the impact of cooling water, of mixing freshwater with salt water, of discharging industrial waste into water, and other "sacrilegious" actions that impeded the ability of Māori to exercise kaitiakitanga, an environmental ethic fully discussed below. ${ }^{21}$ The case and the wider strategy became part of a change in consciousness that ultimately led to the introduction of sections 6,7 and 8 of the Resource Management Act 1991, to Treaty Settlements such as the Waikato River Settlement, and, more recently, the inclusion of Te Mana o te Wai ${ }^{22}$ into decision-making frameworks relating to freshwater.

The Resource Management Act 1991 (RMA) is the principal statute for the management of natural resources, including water. The RMA has a single broad purpose of "sustainable management" of natural and physical resources. ${ }^{23}$ The idea of sustainable management stems from the Brundtland Report, which defines "sustainable development" as "development that meets the needs of the present without compromising the ability of future generations to meet their own needs". Sustainable development provided a framework within which to promote economic and social advancement in ways that would avoid environmental degradation and over-exploitation. ${ }^{24}$ 


\section{Linda Te Aho}

In aiming to achieve sustainable management, decision makers are bound to recognise and provide for various matters of national importance, including "the relationship of Maori and their culture and traditions with their ancestral lands, water, sites, waahi tapu [sacred places], and other taonga [treasures]." ${ }^{25}$ Lands, waters, fisheries and reefs have all been identified as such treasures. ${ }^{26}$ The principles of the Treaty of Waitangi are to be taken into account. ${ }^{27}$ And, particular regard is to be had to a list of environmental factors, beginning with "kaitiakitanga", a term now embodied and defined in the Act as "guardianship of resources by the Maori people of the area". ${ }^{28}$ From a Māori perspective, it means so much more, as explained below.

\section{Kaitiakitanga as right and responsibility}

Hūtia te rito o te harakeke, kei whea te kōmako e kō?29

According to Māori laws and customs that existed prior to colonisation, the protection of natural resources was imperative. For instance, when harvesting flax for its medicinal properties or to craft clothing and baskets from its fibres, it is customary that the youngest, finest shoot of the flax plant that grows between two larger parent leaves remains untouched. Harvesters also respect the parent leaves, for they will keep the youngest warm, and ensure the life of the plant. ${ }^{30}$

This ethic of protecting the environment for its own sake, as well as for present and future generations to use and enjoy, is kaitiakitanga. The root word is "tiaki" which means to care for, to foster, to nourish, and the concept of kaitiakitanga is explained by the redoubtable scholar, the Rev Māori Marsden: ${ }^{31}$

The ancient ones (tawhito), the spiritual sons and daughters of Rangi and Papa were the 'kaitiaki' or guardians. Tane was the kaitiaki of the forest; Tangaroa of the sea; Rongo of herbs and root crops; Hine Nui Te Po of the portals of death and so on. Different tawhito had oversight of the various departments of nature. And whilst man could harvest those resources they were duty bound to thank and propitiate the guardians of those resources.

The distinctions between this earth-centred worldview and the anthropocentric worldview outlined earlier in the chapter are obvious. A contemporary example that explains the fullness of kaitiakitanga ${ }^{32}$ comes from the circumstances surrounding a recent environmental disaster that occurred when the container ship MV Rena ran aground on Ōtaiti (Astrolabe Reef) near the North Island city of Tauranga in October 2011. An estimated 350 tonnes of heavy fuel oil leaked from its ruptured hull into the bay. The indigenous groups most affected by the Rena disaster were clear as to their responsibility for the reef: "we inherited a pristine reef and we have an obligation to pass that same pristine reef on to our children and our children's children and beyond." 33

The reef is a significant treasure to the peoples of the harbour. Traditionally, those who fished on the reef would offer incantations to acknowledge and preserve 
the life force of the reef so that it would continue to be a source of sustenance. The right to fish also creates a responsibility to ensure that resources are preserved for the future. This meant that there were seasons, such as breeding times, when a resource might not be taken or used. Or when the numbers of a particular resource were down and needed time to recover. There was also a management regime for the use of a resource. For example, taking of shellfish might be restricted to those of a particular size to preserve breeding stock. ${ }^{34}$ Many Māori continue to exercise these rights and responsibilities to this day.

Kaitiakitanga then is based on both on rights and responsibility. The significance of the reef for less tangible reasons can be difficult for people from other cultures to understand. For the people of the area, the reef and other surface-breaking rocks and reefs are seen as stepping stones for the spirits of their deceased back across to the sea to their ancestral homeland. ${ }^{35}$ The continued presence of the wreck on the reef and the damage that it caused is therefore a source of spiritual distress and has implications on their ability to carry out their kaitiaki obligations. For these reasons, they are of the view that the wreck must be removed in its entirety.

In a report on the Māori claims to the Waitangi Tribunal seeking the removal of the wreck, the Tribunal explained that the Treaty of Waitangi signed by the British Crown and the Indigenous Māori in 1840 requires that the Crown provide ways for Māori to fulfil their obligations as kaitiaki over the things they treasure. ${ }^{36}$ The Crown has opted to allow parts of the wreck to remain, based on its evaluation of "the environmental, cultural and economic interests of New Zealand and the likely cost and feasibility of the complete removal of the wreck including international comparisons". ${ }^{37}$

The Waitangi Tribunal has confirmed that one of the continuing rights held by Māori under the Treaty is the right to exercise political authority or rangatiratanga in the management of their natural resources (whether they still own them or not) through their own forms of local or regional self-government or through jointmanagement regimes at a local or regional level. ${ }^{38}$ As noted above, the framework set out in the RMA provides strong directions which are to be borne in mind at every stage of the planning process. ${ }^{39}$ However, the way in which Māori interests have been evaluated against a host of other matters in the Act has drawn criticism on more than one occasion from the Waitangi Tribunal as being inconsistent with Treaty principles. The Tribunal has concluded that while the RMA originally promised considerable protection for Māori interests, "it has failed to deliver on that promise" and recommended a number of reforms for a Treaty-compliant environmental management regime ${ }^{40}$ These recommendations are not binding on the government, but some of the recommendations for more effective participation are reflected in recent reforms to the RMA that encourage greater participation by Māori in shaping policies and plans for resource management. ${ }^{41}$

\section{A rights discourse}

The sorts of advancements represented by including references to Māori laws and philosophies in resource management legislation follow a long history of 


\section{Linda Te Aho}

strategies by Māori to gain recognition of their traditional rights and title to lands and resources, both domestically and internationally. These strategies have ranged from passive resistance to outright warfare, establishing political forums, bringing grievances to the attention of parliament, the domestic courts and more recently the Waitangi Tribunal as well as deputations to international assemblies such as the United Nations. ${ }^{42}$ Whether framed as aboriginal rights, human rights or rights guaranteed and protected under the Treaty of Waitangi, the result has been that domestic law has become more inclusive of a Māori worldview. In a series of Court of Appeal cases in the 1980s and 1990s, the courts urged the Crown to engage with Māori to address the recognition and protection of rights that were affirmed in the Treaty of Waitangi and claimed in respect of lands, forests and other natural resources. ${ }^{43}$ Ultimately, this led to the development of a process for directly negotiating Treaty settlements, which runs parallel to the Waitangi Tribunal process. With tribunal hearings often taking many years to complete, and the recommendations that follow not being binding on the Crown, some claimants prefer to engage in direct negotiations, bypassing the tribunal process. Where claimants have opted for the tribunal process, the ensuing report often forms the basis for negotiations. Settlements are intended to "heal the past and build a future" by the Crown acknowledging grievances that arise from breaching Treaty of Waitangi principles, and then providing fair, comprehensive, final and durable settlements; as well as establishing an ongoing relationship between the Crown and the claimant group based on the principles of the Treaty of Waitangi. ${ }^{44}$

As explained below, settlements reached in respect of rivers and lakes provide stronger tools than those that exist in the RMA regime to protect the environment, to protect Māori proprietary rights and interests, and to enable Māori to exercise kaitiakitanga. They also embody two of the key concepts that underpin the philosophy of responsibility: collaboration and sustainability ${ }^{45}$

I have written elsewhere about an innovative power-sharing model for restoring a major river in New Zealand that attempts to integrate Western legal concepts with Māori legal concepts. ${ }^{46}$ In addressing claims that focus on the degradation of the Waikato River, the settlement legislation recognises the river as an ancestor with its own life force, and has as its overarching purpose, the restoration and protection of the health and wellbeing of the river for present and future generations. The settlement has ushered in a new era of co-management that has led to changes in regulatory frameworks regarding land use and freshwater, as well as changes in community expectations. ${ }^{47}$ In the wake of the river settlement, two seats on the regional council, which makes major decisions in respect of freshwater management, are now reserved for Māori, and the Council has shown leadership in exploring pathways to improve relationships with local Māori. Excellent platforms exist in planning documents for recognising Māori rights and interests. There are issues around implementation and enforcement, but there is no doubt that the landscape has changed. These co-management models are becoming increasingly common and include joint management regimes for reserves, mountains, national parks, islands, rivers and lakes. They restore Māori to governance roles and restore direct relationships with natural resources, with the overarching 
purpose being, more often than not, to restore and protect the health and wellbeing of the natural world for future generations. ${ }^{48}$

One settlement that has attracted global attention recently is the settlement for the Whanganui River: ${ }^{49}$

[The river] is ingrained in our hearts and in our minds. I think that this piece of legislation, with its framework that has a human face for our [river], is charged with the responsibility of ensuring that the health and well-being of [the river] - is able to be maintained, not so much for us here today but for future generations.

The settlement deals primarily with the restoration and protection of the health and wellbeing of the river by providing funding for restoration projects and improving planning processes and relationships between local govermment and Māori. In granting legal personality to the river, this settlement gives emphasis to the profound relationships that the local iwi have with their ancestral river and is intended to provide an opportunity for more effective recognition of the rights and interests of the river itself. The settlement explicitly refers to the peoples' responsibilities in relation to the "mana and mouri" of their ancestral river. ${ }^{50}$ It also provides for collaboration and co-management, ${ }^{51}$ and it is telling that the name of the post-settlement governance entity is Ngā Tangata Tiaki, the people who will care for the river.

Though Treaty settlements and the court cases that led to the development of the settlement process were framed in terms of rights to lands and other resources guaranteed and protected under the Treaty of Waitangi, the freshwater settlements are prime examples of the battle to protect those rights being underpinned by principles of responsibility. Similar insights can be found in the articles of the United Nations Declaration on the Rights of Indigenous Peoples.

\section{United Nations Declaration on the Rights of Indigenous Peoples}

As a state, New Zealand participated from the early stages of drafting the United Nations Declaration on the Rights of Indigenous Peoples. ${ }^{52}$ Nganeko Minhinnick and her family became involved in the shaping of the Declaration from the 1980s. They along with others, such as Moana Jackson and Aroha Mead, made a significant contribution, working alongside other indigenous representatives in advocating a model of indigenous rights, as human rights, based on indigenous peoples' similar experiences of colonisation and settlement. ${ }^{53}$ The result is a Declaration that affirms a right to self-determination, historical redress, free prior and informed consent, and rights to property and culture. ${ }^{54}$ Sir ET Durie celebrated state support of the Declaration: ${ }^{55}$

Notwithstanding the progress made through all the tribunal reports and court cases from the 1980s, and the consequential changes in legislation and official policy, I would still rank the day that New Zealand gave support to the 


\section{Linda Te Aho}

Declaration as the most significant day, in advancing Maori rights, since 6th February 1840.

In affirming rights to language, culture, traditions and philosophies, and the right to act freely in pursuing these, rights articulated in the Declaration are underpinned by notions of responsibility. ${ }^{56}$

Now that the dust has settled on the negotiations and endorsement phases in respect of the Declaration, focus has moved to overcoming challenges in implementing the Declaration amongst criticism regarding the degree of compromise reflected in the ultimate form of the Declaration. Some of this criticism will be considered below in the context of a theme of this chapter, that the history of Māori responsiveness demonstrates flexibility and pragmatism in strategies to reconcile grievances.

\section{Conceptions of property and ownership}

A significant part of that history relates to the dispossession and destruction of lands and waters. Concepts that continue to perplex Māori minds are those of property and ownership. According to oral tradition, land is a source of identity for Māori. Being direct descendants of the Earth Mother, Papatūānuku, Māori see themselves as not only "of the land", but "as the land". ${ }^{77}$ Possession of land was custodianship,

a caretaking for future generations, and an acknowledgement of the temporariness of individual human life ... A vast number of Maori people, when questioned, will respond: 'The land is my Mother. I cannot sell her - for if I do, I sell part of myself. ${ }^{58}$

Legislation converted and assimilated Māori customary land tenure into what would become the New Zealand land law system, constituting a basis of ownership previously quite unknown to Māori. ${ }^{59}$ However, when bringing challenges before the courts, Māori framed their claims in the language that the colonisers understood, such as aboriginal title, or breaches of rights that had been guaranteed in the Treaty.$^{60}$ As a result, the common law of New Zealand recognises the pre-existing property rights and cultural rights of Māori as a qualification on the sovereign title of the Crown: ${ }^{61}$

Aboriginal title is a compendious expression to cover the rights over land and water enjoyed by the indigenous or established inhabitants of a country up to the time of its colonisation. On the acquisition of the territory, whether by settlement, cession or annexation, the colonising power acquires a radical or underlying title, which goes with sovereignty. Where the colonising power has been the United Kingdom, that title vests in the Crown. But, at least in the absence of special circumstances displacing the principle, the radical title is subject to the existing native rights. 
This position was reaffirmed in the Ngati Apa case where the Court of Appeal confirmed the jurisdiction of the specialist Māori Land Court to investigate the status and ownership of land as Māori customary land, in relation to the foreshore and seabed. It also found that rangatiratanga and kaitiakitanga status and obligations as affirmed in the Māori version of the Treaty of Waitangi encompass a wider application than simply possession, occupation and use rights as captured in the common law doctrine of aboriginal title. Aboriginal title rights range from hunting, fishing and other types of access and passage through to exclusive ownership. ${ }^{62}$ The Crown has recognised prior rights to lands, fisheries and forests. Whilst the Crown maintains that there is no right to own water at common law, this position is the subject of ongoing debate. ${ }^{63}$ In the absence of clear and plain legislative direction to extinguish such rights (as occurred in the case of minerals and the foreshore and seabed), it remains open to argue that Māori have ownership rights in freshwater. ${ }^{64}$

The Waitangi Tribunal has found that Māori rights in 1840 included rights of authority and control over taonga (treasures), and are rights that are akin to the English concept of ownership. ${ }^{65}$ It has also said that a right to development of property or taonga is guaranteed under Te Tiriti o Waitangi. ${ }^{66}$ The freshwater settlements do not provide for ownership in water, and they vary in respect of transferring title to the beds of lakes and rivers.

The Waikato River settlement did not incorporate the return of the riverbed, and the issue of ownership of water was explicitly deferred. To ensure that WaikatoTainui's position as to their authority over the Waikato River is made clear, the preamble to the settlement Act records a statement from the time they first became concerned that the Crown might itself claim authority over the river. When the governor's intentions to put an iron steamer on the river became known late in 1862, Patara Te Tuhi, editor of the tribal newspaper, expressed the opposition of the chiefs warning that the gunboat might not enter the river without permission. $\mathrm{He}$ asserted tribal authority over the river in these words: "E hara a Waikato awa $\mathrm{i}$ a te kuini, engari no nga Māori anake". (The Waikato River does not belong to the Queen of England, it belongs only to Māori). ${ }^{67}$ Other provisions were included in the Act to record the agreement to defer any engagement about water ownership should the Crown change its position. ${ }^{68}$

The Te Arawa Lakes Settlement Act 2006 vests the lakebeds in the relevant tribal confederation, but the Crown retains ownership of the "stratum", the fictional space occupied by water and the space occupied by air above each $\mathrm{Te}$ Arawa lakebed. ${ }^{69}$ These mechanisms were created to avoid Māori owning water and the space above water, thus preventing any charging for use of either. There are some Māori groups who maintain that water is incapable of being owned. ${ }^{70}$ For example, the Whanganui River settlement transfers title to Crown owned parts of the riverbeds, but contains explicit statements regarding ownership. The legislation makes it clear that vesting of the riverbed does not create or transfer a proprietary right in water. ${ }^{71}$ Because of this, the Whanganui River settlement falls short of the Waitangi Tribunal's recommendations in its substantial Whanganui River Report of 1999. There the Tribunal recommended, among other things, that 


\section{Linda Te Aho}

the Crown negotiate with Whanganui iwi with a view to vesting the river in its entirety in an iwi ancestor, and that resource consent applications in respect of the River would require the approval of the iwi governance entity. ${ }^{72}$

The legislative solution to the controversy around the potential for Māori to own foreshore and seabed was to clearly and plainly vest the foreshore and seabed in the Crown. That legislation was replaced by an Act that declares the foreshore and seabed incapable of ownership and recognises certain customary rights. ${ }^{73}$ In light of the Waitangi Tribunal's report on Māori rights and interests in water, and political tension around Māori ownership of natural resources, the government has engaged in a process to explore ways of recognising Māori rights and interests whilst maintaining its position that water is incapable of being owned. In this context, Māori-generated research has found that stronger tools that are additional to, and that complement, Treaty settlements are needed to appropriately recognise Māori rights and interests in freshwater to enable the exercise of rangatiratanga and kaitiakitanga.

The Durie proposal is one such solution, and insofar as it references the philoşophy of responsibility and draws upon Māori laws of kaitiakitanga, it seems like an elegant solution consistent with international trends.

\section{A responsibility discourse}

The philosophy of responsibility refers to the respectful relationship human beings can have with their social and natural environment. While a duty is something imposed by others, responsibility invokes an ability to respond, to make choices. ${ }^{74}$ Initiatives such as the Earth Charter and the Charter for Human Responsibility, and indigenous initiatives such as the Rights of Mother Earth proposed by Bolivia, are global examples of "reaching towards responsibility for the viability of life on the planet." 75

\section{The Earth Charter}

The 1992 United Nations Conference on Environment and Development (also known as the Rio de Janeiro Earth Summit) created a movement for sustainable development as a way to address climate change challenges. Following the conference, the Earth Charter was developed to focus attention on environmental devastation, depletion of resources and extinction of species occurring as a result of economic over-exploitation of ecosystems. The Earth Charter provides a shared vision based on basic values: respect and care for the community of life, ecological integrity, social and economic justice, democracy, nonviolence and peace. It urges action. Champions of the Earth Charter such as the Global Ecological Integrity Group ${ }^{76}$ call for a radical change of ethical outlook, drawing upon the wisdom of Aldo Leopold, who wrote in 1948: $:^{77}$

We abuse land because we regard it as a commodity belonging to us. When we see land as a community to which we belong, we may begin to use it 
with love and respect. There is no other way for land to survive the impact of mechanized man.

The proposition of a Charter of Human Responsibilities builds on the groundwork of the Earth Charter. According to the preamble: ${ }^{78}$

The burden of collectively caused damage must be morally acknowledged by the group concerned, and put right in practical terms as far as possible. Since we can only partially understand the consequences of our actions now and in the future, our responsibility demands that we must act with great humility and demonstrate caution.

This charter is a step towards developing a democratic global governance based on human responsibilities, and towards developing a legal framework within which these responsibilities may be exercised. It recognises that sometimes society faces hard choices, such as the need to encourage economic development while protecting the environment and respecting human rights. In such cases, human responsibility dictates that none of these imperatives should be sacrificed to the others.

Proponents of responsibility draw upon the work of philosophers such as Emmanuel Levinas and Karen Barad. ${ }^{79}$ They emphasise "responsiveness", or "responsability", rather than "a burdensome sense of guilt". ${ }^{80}$ They also recognise that indigenous peoples have long articulated a discourse of "relational responsibility", an obligation to others and to natural environments, for "relationality is at the heart of indigenous consciousness." ${ }^{81}$ As discussed in the Māori case studies above, there is a strong resemblance between the basic values of these charters and indigenous wisdom. ${ }^{82}$

\section{Indigenous solutions - living well with the earth}

In arguing that the existing sustainable development agenda has not delivered on its promise of improved environmental sustainability, Deborah McGregor postulates that many international undertakings, including those led by the United Nations, continue to marginalise the involvement and voice of indigenous peoples. ${ }^{83}$ Perhaps this is the reason that the Earth Charter and the Charter for Human Responsibility have not attracted the same levels of attention in New Zealand as compared with the developments in South America and the United Nations Declaration on the Rights of Indigenous Peoples. ${ }^{84}$

Turning to South America first, Bolivia passed the Rights of Mother Earth Act 2010 recognising Mother Earth as a living dynamic system (article 3) and granting her comprehensive legal rights that are comparable to human rights. Under article 7, Mother Earth has a number of rights including the right to life - the right to maintain the integrity of living systems and natural processes that sustain them as well as the capacities and conditions for regeneration. Other rights include the right to diversity of life, to water, to clean air, to balance, to restoration, and to live free of pollution. The object of the Act is to recognise these rights, as well as 


\section{Linda Te Aho}

the obligations and duties of the plurinational state and of the society to ensure respect for these rights (article 1). Despite concerns about the perceived idealism, and questions about how the laws will be realised on the ground, these laws recognise that the world community is pushing Mother Earth past sustainable limits. Article 5 recognises the earth as being of public interest. Often, public interest trumps environmental concerns, and the public interest in not often defined as the wellbeing of the earth community or the earth, but is determined by largely economic standards. At the very least, the Bolivian laws recognise in a substantive way that humans will not thrive if the earth as a whole cannot.

The 2008 Ecuador Constitution also provides for legally enforceable Rights of Nature. Under article 395, the State guarantees

a sustainable model of development, one that is environmentally balanced and respectful of cultural diversity, conserves biodiversity and the natural regeneration capacity of ecosystems, and ensures meeting the needs of present and future generations.

The Constitution is supreme law, and provides that any international treaties entered into shall be subject to its provisions.

More recently, the Rio+20 Declaration: Indigenous Peoples International Declaration on Self-Determination and Sustainable Development offered an alternative paradigm for achieving sustainable development: ${ }^{85}$

Indigenous peoples call upon the world to return to dialogue and harmony with Mother Earth, and to adopt a new paradigm of civilisation based on Buen Vivir - Living Well. In the spirit of humanity and our collective survival, dignity and well being, we respectfully offer our cultural world views as an important foundation to collectively renew our relationships with each other and Mother Earth and to ensure Buen Vivir/living well proceeds with integrity.

The Rio+20 Declaration rejects the "dominant neo-liberal concept and practice of development based on colonisation, commoditization, contamination and exploitation of the natural world and policies and projects based on this model"86 and calls for the renewal of a more ancient concept of sustainability, as expressed through the notion of living well. ${ }^{87}$

There is a clear correlation between the aspirations of the Earth Charter and the Charter for Human Responsibilities and those of indigenous peoples in relation to the environment, all offering alternative frameworks for living on this earth and in our environment. However, Māori emphasise that their rights and responsibilities in respect of kaitiakitanga exist in a delicate balance with their proprietary and development rights.

\section{Contemporary discourses}

We believe we have a right to be involved in the management of water, and we also believe that we have a right to an allocation of water ... If you look at all iwi in 
the country we are staunch on kaitiakitanga, but we're also all actively involved in business, and yes we will be using [water] economically. ${ }^{88}$

The Iwi Chairs Forum is a platform for sharing knowledge and information across tribal groups. Iwi leaders are clear in their view that kaitiakitanga and cultural rights include rights of sustainable and commercial use. A recent example is that of Māori opposing the establishment of an ocean sanctuary as a breach of their rights affirmed in a national fisheries settlement, demonstrating that while conservation principles are high on their agenda, they also have to protect their commercial and economic rights. ${ }^{89}$

Iwi leaders have continued to champion improvements to water quality, seeking to expand some of the best practice models from the freshwater settlements. ${ }^{90}$ They have worked with the Crown in ensuring that the national significance of freshwater is recognised in policy by incorporating the principle of "Te Mana o te Wai". This principle recognises the innate relationship between the health and wellbeing of water and the wider environment, and their ability to support each other, while sustaining the health and wellbeing of the people. At the same time, iwi leaders have commissioned research into how Māori proprietary rights in water might be reflected in the creation of a fairer process for distribution and allocation of water. The current process for allocation is based on a premise of "first in first served". Māori are advocating for a system that encourages efficiency and discourages water hoarding. Iwi leaders are proposing that limits on water takes are set and enforced, and then focus can shift to sustainable use of the remaining allocatable flow. This, too, is a way of giving effect to Treaty rights and interests and ensuring that Māori and new users who can demonstrate that they are good kaitiaki of the water have fair access to water for sustainable development options that enable and protect Te Mana o te Wai. ${ }^{91}$

Proposals being put forward by Māori groups such as the iwi leaders and the New Zealand Māori Council acknowledge that while the co-management regimes established under the freshwater Treaty settlements provide some recognition of Māori rights and interests, they do not go far enough. In light of the Crown's continuing policy that no one owns water and recognising that the dominant legal system in New Zealand prioritises proprietary rights, Māori have proposed pathways forward that avoid the ownership issue. Instead, they focus upon drawing out the strongest mechanisms from the freshwater settlements:

1 Vesting ownership of riverbeds and lakebeds in iwi without the need for individual Treaty settlement processes. Title could be declared to be inalienable title under iwi control.

2 Vesting ownership of the "water column" in iwi, providing them with strong leverage in their communities to ensure that their respective rights and interests are recognised in ways that align with their values and responsibilities and that also allow them to commercialise their property rights if they so desire. A precedent for this is the Lake Taupō model. Lake Taupō is an iconic lake in the central North Island. Key elements of the arrangements in respect 


\section{Linda Te Aho}

of the lake, relevant to the rights and interests discussion, include that iwi own the lakebed and the "water column" (the fictional area that surrounds the water in flow). This mechanism has provided strong leverage for the iwi to ensure their rights and interests are recognised in ways that align with their values and obligations as kaitiaki and that also allow them to once again commercialise their property rights. Historically, the iwi charged for transporting products such as milk across the lake and for fishing guide services. It is an excellent example of how the Crown has given over real rights to iwi that has made them "significant players" in their communities and have provided commercial opportunities. ${ }^{92}$

\section{A discourse of compromise}

Avoiding the controversial and complicated issue of ownership is a thread in a pattern of pragmatism and compromise. This pattern is demonstrated in the focus on enhancing a single justice system that better recognises indigenous laws "for the sake of national cohesion" rather than advocating for a plural legal order. ${ }^{93} \mathrm{Ani}$ Mikare has warned that Māori should not ${ }^{94}$

settle for mere improvements in the Pākehā system as being the ultimate goal. It is all very well to be making Pākehā law and legal institutions as Māori friendly as possible, but only so long as we do not become comfortable that we forget to aim for something more ... to remind ourselves constantly about what it is that tino rangatiratanga ultimately demands.

The result of making mere improvements to a single justice system has been the undermining of Māori rights and interests as the rights and interests of others are given more weight. ${ }^{95}$ Consequently, the environment has suffered. Compromise is evident in the political compacts that are the freshwater settlements. It is evident, too, in the wording and description of the United Nations Declaration on the Rights of Indigenous Peoples (the Declaration). In relation to the Declaration, New Zealand objected to the notion of human rights as collective rights, arguing "human rights are universal and apply in equal measure to all individuals, meaning that one group cannot have human rights that are denied to other groups within the same nation-state." 96 Andrew Erueti discusses the refusal by successive govemments to recognise Māori political and property rights on the basis that this would be discriminatory to non-Māori. Erueti concludes that this approach "reads down" the article 2 guarantee to Māori of tino rangatiratanga. ${ }^{97}$ New Zealand's later support of the Declaration was based on the premise that the document is non-binding, "an expression of aspiration" which will "have no impact on New Zealand law and no impact on the constitutional framework."98 Karen Engle has decried the significant compromises in the Declaration and the serious limitations to the very rights it is praised for containing. In Engle's view, indigenous advocates compromised too much by pursuing a strategy of emphasising cultural elements of their claims and downplaying claims to "strong forms of 
self-determination", for example, "right of secession or independence as a nation state." 99 The effect has been to "reify identity and indigenous rights and displace many of the economic and political issues that initially motivated much indigenous advocacy: issues of economic dependency, structural discrimination, and lack of indigenous autonomy." 100

\section{Conclusion}

Conscious of the degradation and depletion of natural resources and the breakdown of natural systems, there is a growing number of global movements looking to better protect this planet. Examples from New Zealand illustrate how Māori have responded to climate and environmental challenges over generations by asserting their rights and responsibilities in respect of their lands and waters. As a result, among other things, state law is becoming more accommodating of Māori laws, values and worldviews. But the reality of progressing rights in an era of practical reconciliation is an ongoing series of compromises for Māori, given the state's reluctance to adapt British legal notions of property in relation to water, and the related mindset that the recognition of Māori property rights to water is undemocratic privilege. The proposal to move towards a governance framework for freshwater based on responsible use is worth further consideration as an elegant solution to encourage respect for difference, and to find agreement for direction moving forward.

\section{Notes}

1 Ngahuia Te Awekotuku "He Wāhine, He Whenua, Māori Women and the Environment" in Mana Wāhine Māori (New Women's Press, Auckland, 1991) 66 at 70.

2 E.T. Durie "Law, Responsibility and Maori Proprietary Interests in Water" (paper presented at Law, Governance and Responsibility, University of Waikato, Hamilton, November 2014), also Chapter 10 in this volume. Sir E.T. Durie is a former Chief Judge of the Māori Land Court and High Court Judge, and is the Chair of the New Zealand Māori Council and its spokesperson on freshwater issues. Since the publication of Durie's proposal, political parties have produced water policies that involve some form of water levy that will contribute to restoring water quality. Some also recognise a Māori proprietary right.

3 Waitangi Tribunal The Stage 1 Report on the National Freshwater and Geothermal Resources Claim (Wai 2358, 2012) at 14.

4 The Treaty of Waitangi, signed between the British Crown and Māori in 1840, guaranteed Māori the full exclusive and undisturbed possession of their lands and estates, forests, fisheries and other properties which they desired to retain. The Mãori version guaranteed "tino rangatiratanga", full authority and rights to govern. Whichever version one accepts, there is a clear recognition of and protection for Māori rights to govern natural resources, which they desired to retain.

5 Te Ahukaramu Royal and Betsan Martin "Indigenous Ethics of Responsibility in Aotearoa New Zealand: Harmony With the Earth and Relational Ethics" in Edith Sizoo (ed) Responsibility and Cultures of the World: Dialogue Around a Collective Challenge (6th ed, Peter Lang, Brussels, 2010) 47 at 48. See also T.K. Hoskins "Māori and Levinas: Kanohi ki te Kanohi for an Ethical Politics (PhD thesis, University of Auckland, 2010) cited in T.K. Hoskins, B. Martin, M. Humphries "The Power of Relational Responsibility" (2011) Electronic Journal of Business Ethics and Organizational Studies 6. 


\section{Linda Te Aho}

6 Royal and Martin, above $\mathrm{n} 5$.

7 Deborah McGregor "Living Well With the World" in Corinne Lennox and Damien Short (eds) Handbook of Indigenous Peoples' Rights (Routledge, Oxford, 2016) 167 at 169 .

8 A term used by Tom Bennion "Impact on Resource Management Practice" (paper presented at the "Huakina: 'Tihe Fabric of New Zealand Society': A 30 Year Retrospective and Way Forward" Conference, Waikato Tainui College of Research and Development, Hopuhopu, June 2017).

9 Ministry for the Environment "Our Clean Green Image, What's It Worth" (2001) $<$ www.mfe.govt.nz>. Mike Joy "The Dying Myth of a Clean, Green Aotearoa" The New Zealand Herald (online ed, Auckland, 25 April 2011).

10 Tom Bennion, above n 8, citing the National Institute of Weather and Atmospheric Conditions: <www.niwa.co.nz/>.

11 Adrian Macey, Chapter 7, this volume.

12 These are aspirational standards in government policy: <www.mfe.govt.nz/> and $<$ www.waikatoregion.govt.nz/ >. See Adrian Macey, Chapter 7.

13 Lara Burkhardt "A Freshwater Allocation to Iwi: Is it Possible Under the Resource Management Act 1991?" (2016) 24 Waikato Law Review 81-96.

14 Alexander Gillespie International Environmental Law, Policy, and Ethics (2nd ed, Oxford University Press, Oxford, 2014) at 4.

15 Embrey v. Owen (1851) 6 Exch 353 at 372-373, 155 ER 579; Linda Te Aho "Ngā Whakataunga Waimāori" in Janine Hayward and Nicola Wheen (eds) Treaty Settlements (Bridget Williams Books, Wellington, 2012) 102.

16 Nicola Wheen "A Natural Flow: A History of Water Law in New Zealand" (1997) 9 Otago Law Review 71 at 78 .

17 Public Works Amendment Act 1889.

18 Land Drainage Act 1893.

19 The Tribunal is a permanent bicultural commission of inquiry that hears claims and makes recommendations about breaches of the Treaty of Waitangi: see www.waitan gitribunal.govt.nz/. The Tribunal's report on the Kaituna River Claim (Wai 4, 1984) made recommendations upon an application to abandon a scheme to build a pipeline from a wastewater treatment plant to a culturally significant river.

20 Huakina Development Trust v. Waikato Valley Authority [1987] 2 NZLR 188 (HC) at 210 per Chilwell J.

21 For example: Decisions of the Planning Tribunal, A116/84 ; A661/84; A 119/84; A120/84; and Waitangi Tribunal Report of the Waitangi Tribunal on the Manukau Harbour (Wai 8, 1985).

22 The principle of "Te Mana o te Wai" recognises the innate relationship between the health and well-being of water and the wider environment, and their ability to support each other, while sustaining the health and well-being of the people. It is discussed more fully below.

23 Resource Management Act 1991, s 5.

24 Geoffrey Palmer QC "The Resource Management Act - How We Got It and What Changes Are Being Made to It" (paper presented to Resource Management Law Association, Devon Hotel, New Plymouth 27 September 2013).

25 Section 6(e).

26 Waitangi Tribunal The Final Report on MV Rena and Motiti Isalnd Claims (Wai 2391 and 2393, 2015) [Rena Report].

27 Resource Management Act 1991, s 8. The principles of the Treaty emerged from a series of Court of Appeal cases in the 1980s where Māori opposed the transfer of state-owned assets to separate legal entities, thereby putting them beyond the reach of Māori claims under the Treaty. For a criticism of the principles, see Jane Kelsey $A$ Question of Honour: Labour and the Treaty 1984-1989 (Allen \& Unwin, Auckland, 1990) at 217. 
28 Resource Management Act 1991, s 7(a).

29 Traditional saying "If you remove the young shoot, from where will the bellbird sing?"

30 Te Awekotuku, above n 1, at 66.

31 There is reference here to the children of Rangi, the sky father, and Papa, the earth mother in Māori creation stories. Te Ahukaramu Charles Royal (ed) The Woven Universe: Selected Writings of Rev Maori Marsden (Estate of Maori Marsden, Otaki, 2003) at 67 cited in R. Benton, A. Frame and P. Meredith Te Matapunenga: A Compendium of References to the Concepts and Institutions of Māori Customary Law (Victoria University Press, Wellington, 2013) at 112.

32 I have written extensively about kaitiakitanga and freshwater elsewhere. See, for example, L. Te Aho "Indigenous Challenges to Enhance Freshwater Governance and Management in Aotearoa New Zealand - The Waikato River Settlement" (2010) 20 The Journal of Water Law 285; L. Te Aho "Ngā Whakataunga Waimāori: Freshwater Settlements" in N.R. Wheen and J. Hayward (eds) Treaty of Waitangi Settlements (Bridget Williams Books Ltd, Wellington, 2012) ch 7.

33 Rena Report, above n 23, at 14.

34 Ibid. at 14.

35 Ibid.

36 Ibid. at 12 .

37 Ibid. at 36.

38 Waitangi Tribunal Ko Aotearoa Tenei Te Taumata Tuatahi (Wai 262, 2011) at 112.

39 McGuire v. Hastings District Council [2001] NZRMA 557 at 566.

40 Waitangi Tribunal Ko Aotearoa Tenei Te Taumata Tuarua (Wai 262, 2011) ch 3.

41 Recently enacted Resource Management Act amendments provide for Mana Whakahono a Rohe arrangements (MWR). MWR are written agreements between local govemment and iwi authorities to record how the latter will participate in the preparation, change or review of a policy statement or plan, Resource Management Act 1991, ss $58 \mathrm{O}-58 \mathrm{U}$

42 These strategies have not been linear and are well documented. For a general discussion, see Ranginui Walker Ka Whawhai Tonu Matou, Struggle Without End (Penguin, Auckland 1990).

43 New Zealand Māori Council v. Attorney General [1987] 1 NZLR 641 (CA); New Zealand Māori Council v. Attorney General [1989] 2 NZLR 143 (CA) New Zealand Māori Council v. Attorney General [1994] 1 NZLR 513 (CA); New Zealand Māori Council v. Attorney General [1996] 3 NZLR 140 (CA).

44 Office of Treaty Settlements Ka Tika a Muri, Ka Tika a Mua: Healing the Past and Building a Future (2nd ed, Office of Treaty Settlements, Wellington, 2015) at 23.

45 Te Ahukaramu Royal and Betsan Martin, above n 5, at 62.

46 See Te Aho, above n 32.

47 Waikato Regional Council Healthy Rivers Plan Change project and process: <www. waikatoregion.govt.nz/healthyrivers/>.

48 Examples include Ngāi Tahu Claims Settlement Act 1998; Te Arawa Lakes SettlementAct 2006; Ngāti Pāhauwera Treaty Claims Settlement Act 2012; Tapuika Claims Settlement Act 2014

49 Adrian Rurawhe, Member of Parliament for the area. First Reading of Te Awa Tupua (Whanganui River Claims Settlement) Bill (24 May 2016) 714 NZPD 11220.

50 See Te Awa Tupua (Whanganui River Claims Settlement) Act 2017, s 71(1)(b) and (2)(c).

51 Sections 27-34.

52 United Nations Declaration on the Rights of Indigenous Peoples GA Res 61/295, A/ RES/47/1 (2007) [UNDRIP].

53 Aroha Mead "Keynote Presentation" (paper presented to the He Manawa Whenua Conference, Hamilton, March 2017). 


\section{Linda Te Aho}

54 Andrew Erueti "Implementation of the United Nations Declaration on the Rights of Indigenous Peoples in Aotearoa - Theory and Practice" <www.waikato.ac.nz/law/newsevents/undrip-symposiun/context>.

55 Sir E.T. Durie quoted in Tracy Watkins, "Judge Hails Big Advance for Maori" < stuff. co.nz> (online ed, New Zealand, 22 April 2010).

56 See for example UNDRIP, above n 50, arts 3, 8, 9, 11-16, 26, 27, and 31.

57 Ministry of Justice "Whenua" in He Hinatore ki te Ao Mãori a Glimpse into the Mãori World (Ministry of Justice, Wellington, 2001) 43 at 44.

58 Te Awekotuku, above n 1, at 68-69.

59 In re the Bed of the Whanganui River [1962] NZLR 600 (CA) per Gresson P.

$60 R$ v. Symonds (1847) NZPCC 387; Wi Parata v. the Bishop of Wellington (1877) 3 NZ Jur (NS) 72 (SC); Nireaha Tamaki v. Baker [1901] A C 561 (PC); Tamihana Korokai v. Solicitor-General (1912) 32 NZLR 321 (CA); Te Weehi v. Regional Fisheries Office (1986) 1 NZLR 682 (HC).

61 Te Runanganui o Te Ika Whenua Inc Society v. Attorne'y-General [1994] 2 NZLR 20 (CA). In this case, the Court found that there was no aboriginal right to generate electriciy. The common law principle regarding aboriginal title was affirmed in $\mathrm{Ngati}$ Apa v. Attorney-General [2003] 3 NZLR 643 (CA) [Ngati Apa].

62 Ngati Apa, above n 61, at [33] per Elias J.

63 Embrey v. Owen, above n 15. See also Report to the Iwi Advisory Group from the 'Freshwater Iwi Regional Hui, November 2014 at $10<$ http://iwichairs.maori.nz/>

64 Jacinta Ruru "Maori Legal Rights to Water: Ownership, Management, or Just Consultation?" (2011) Resource Management Theory and Practice 119 at 120-123. The Crown Minerals Act 1991, section 10, claims all petroleum, gold, silver and uranium existing in its natural condition in the land (whether or not the land has been alienated from the Crown) as the property of the Crown. The Marine and Coastal Area (Takutai Moana) Act 2011 creates a special status for the common marine and coastal area and says that it is incapable of ownership, although the Act recognises customary interests in the area and customary marine title in sections 11 and 58.

65 See Waitangi Tribunal Te Ika Whenua Rivers Report (Wai 212, 1998) at 126. See, generally, Waitangi Tribunal The Whanganui River Report (Wai 167, 1999), and more recently, Waitangi Tribunal The Stage 1 Report on the National Freshwater and Geothermal Resources Claim, above $\mathrm{n} 3$, at 80.

66 Waitangi Tribunal Te Ika Whenua Rivers Report (Wai 212, 1998) at 120.

67 Ibid. at [4].

68 Waikato-Tainui Raupatu Claims (Waikato River) Settlement Act 2010, ss 64 and 90.

69 Te Arawa Lakes Settlement Act 2006, s 23.

70 Iwi Leaders Report on Freshwater, above n 63.

71 Te Awa Tupua (Whanganui River Claims Settlement) Act 2017, s 46.

72 The Waitangi Tribunal Whanganui River Report (Wai 167, 1999) at 343.

73 Marine and Coastal Area (Takutai Moana) Act 2011.

74 Pierre Calame and Edith Sizo "Towards a 2015-2025 Strategy to Promote a Global Culture of Responsibility and Responsibility-based Legislation" at 1.

75 Hoskins, Martin and Humphries, above n 5, at 24.

76 Laura Westra and Mirian Vilela (eds) The Earth Charter, Ecological Integrity and Social Movements (Routledge, New York, 2014).

77 Aldo Leopold, A Sand County Almanac and Sketches Here and There (Oxford: Oxford University Press, 1968, viii-ix; as quoted by Prue Taylor and David Grinlinton in Property Rights and Sustainability (Martinus Nijhoff, The Hague, 2011) at 1.

78 The Earth Charter: A Declaration of Fundamental Principles for Building a Just Sustainable, And Peaceful Global Society in the 21st Century (Earth Charter Commission, The Hague, 2000), see <www.earthcharter.org>.

79 Betsan Martin "Reponsibility Matters: A Perspective for Public Good" at 1 <www. waikato.ac.nz/_data/assets/pdf_file/0020/227351/Martin-Responsibility-MattersPublic-Policy-Nov2014.pdf>. 
80 Royal and Martin, above $\mathrm{n} 5$, at 1.

81 Ibid. at 3.

82 See also Linda Te Aho "Indigenous Aspirations and Ecological Integrity: Restoring and Protecting the Health and Wellbeing of an Ancestral River for Future Generations in Aotearoa New Zealand" in L. Westra, K. Bosselmann and C. Soskolne (eds) Globalisation and Ecological: Integrity in Science and International Law (Cambridge Scholars Publishing, Newcastle upon Tyne, UK) at 346.

83 Deborah McGregor "Living Well With the Earth" in Corinne Lennox and Damien Short (eds), Handbook of Indigenous Peoples' Rights (Routledge, London, 2016) ch 12.

84 Discussed above in text to $\mathrm{n} 51$ and 52.

85 Rio+20 International Conference of Indigenous Peoples on Self--Determination and Sustainable Development, 19 June, 2012, Rio De Janeiro. Adopted by networks, organizations, traditional leaders, spiritual leaders and indigenous peoples from the 7 regions of the world, participants of the Conference. Endorsed by Campamento Terr Livere-Culpa dos Provos. See <www.iitc.org/wp-content/uploads/2013/07/>, at [3].

86 Ibid. at [16].

87 McGregor, above n 78.

88 Sir Mark Solomon, on behalf of the Iwi Chairs Forum, Waitangi 2016.

89 Te Ohu Kaimoana <www.teohu.maori.nz/>.

90 Waikato Regional Council Healthy Rivers Plan Change project and process: <www. waikatoregion.govt.nz/healthyrivers/>; and see http://iwichairs.maori.nz/our-kaupapa/ fresh-water/.

91 Burkhardt, above $\mathrm{n} 13$.

92 "Te Hapori o Maungatautari" Case Study Report: <http://iwichairs.maori.nz/our-kaupapa/ fresh-water/> at 4 .

93 Moana Jackson "Māori and the Criminal Justice System: A New Perspective, He Whaipaanga Hou" (Department of Justice, Policy and ResearchDivision, Wellington, 1997).

94 Ani Mikaere "Tikanga as the First Law of Aotearoa" (2007) 10 Yearbook of New Zealand Jurisprudence 24 at 26.

95 Te Runanga o Ngai Te Rangi Iwi Trust v. Bay of Plenty Regional Council [2011] NZ EnvC 402.

96 HE Ms Rosemary Banks "Statement on behalf of Australia, New Zealand and the United States" <www.australian.org/unny/Soc_161006.html> and cited by Karen Engle, "On Fragile Architecture: The UN Declaration on the Rights of Indigenous Peoples in the Context of Human Rights" (2011) 22 EJIL 141 at 146. See also the discussion in Andrew Erueti "Māori Rights to Freshwater: The Three Conceptual Models of Indigenous Rights (2016) Waikato Law Review 1.

97 Erueti, above $\mathrm{n} 97$ at 6-7.

98 (20 April 2010) 662 NZPD 10238 (Prime Minister John Key).

99 Engle, above, $\mathrm{n} 97$, at 145 and 147.

100 Erueti, above n 97, at 1. 